\title{
Changes and challenges in telecommuting explained through multi-level perspective on socio technical transition
}

\author{
Roxana SÂRBU \\ Bucharest University of Economic Studies, Bucharest, Romania \\ roxana.sarbu@ase.ro \\ Victor Marian DUMITRACHE \\ Bucharest University of Economic Studies, Bucharest, Romania \\ victor.dumitrache@gmail.com \\ Cristina ALPOPI \\ Bucharest University of Economic Studies, Bucharest, Romania \\ calpopi07@yahoo.com \\ Petrut Cristian VASILACHE \\ Bucharest University of Economic Studies, Bucharest, Romania \\ cristian@vpcpartners.ro
}

\begin{abstract}
COVID-19 was responsible for a global health crisis beginning in early 2020 that saw telecommuting become commonplace regardless of the size of the firm, the sector or country. It's possible that even before pandemics, there were some differences in the practice of telecommuting among countries and sectors. These differences were impacted by factors such as the cultural context and labor policies at governmental and corporate levels. Telecommuting in the EU had only reached 5.4\% in 2019 before the Covid-19 outbreak, making it a relatively new trend when compared to the technological potential it offers. 40 percent of EU workers are expected to telecommute in 2020, in the early stages of the outbreak, according to estimates. This research uses the theory of socio-technical transitions (MLP) to examine how and why telecommuting suddenly became the norm among managers and workers from a variety of different industries. At landscape level, an opening was provided by the Covid-19 epidemic that allowed telecommuting to break over the niche-regime barrier.
\end{abstract}

Keywords: telecommuting, Covid-19, pandemic, sociotechnical system, multi-level perspective.

\section{Introduction}

Telecommuting, also known as working from home, working remotely, or teleworking, is a method of conducting work away from the employer's premises on a regular basis through the use of information technology, in which the employee does not have to commute or go to the employer's location (EU, 2002) Lopez-Igual and colleagues (Lopez-Igual et al. 2020).

Prior to the global health catastrophe that began in early 2020 as a result of the spread of Covid-19, telecommuting had not been prevalent at all, regardless of the size of the business, the industry, or the country in which it took place. Prior to the epidemic, just $15 \%$ of workers in the European Union had ever telecommuted (EU, 2020), with only 5.4 percent of those workers doing so in 2019 (Eurostat, 2020).

However, even though the practice of telecommuting had not been widespread prior to the pandemic crisis, there were some variations based on the country, sector, or organization that were 
influenced by the culture, the labor (Radulescu et al., 2021) both at the governmental and organizational level, the labor market supply, and a variety of other variables. When it comes to national differences, the percentage of employees who worked from home in 2019 ranged from 0.5 percent in Bulgaria and 0.8 percent in Romania to 14.1 percent in Finland and the Netherlands. Eurostat forecasts a rise in the number of people in the EU by 2020.

The practice of telecommuting has also seen changes over time, according to the same source, with the number of dependent employees who practice telecommuting increasing from 7.5 percent in 2009 to $11 \%$ in 2019 . The developments in information technology, as well as changes in the nature of professions, have both had an impact on time variations, with both providing more possibilities and flexibility to work remotely (Profiroiu et al., 2020a; Burlacu et al., 2019).

Telecommunications, and specifically working from home, has become the standard for millions of employees around the world since the onset of a global health crisis in early 2020, according to the World Health Organization. Eurofound (2020) believes that as a result of the epidemic, 40 percent of full-time workers in the EU have begun to telecommute from home.

Prior to the pandemic, telecommuting had been a slowly rising trend in business and research as well, with the majority of its proponents claiming that it represented the future of work (Negescu Oancea, et al., 2020). Despite the promising nature of information and communications technology (ICT) and early optimist expectations, telework had mostly failed to catch the interest and imagination of management and employees. A multi-level perspective (MLP) on the sociotechnical transitions approach was utilized by Hynes (2016) to uncover why telecommuting has remained a 'niche' practice dominated by a narrow collection of sectors, managers, and workers. His work builds on MLP thinking by emphasizing the behavioral, cultural, and political components of socio-technical transformations and their interactions, as well as the interactions between them (Profiroiu et al., 2019). Several factors, including a failure to enroll additional nicheactors, the dominance of traditional forms of working and automobility, a lack of government policy, and a lack of legitimacy, all conspired to prevent telework from moving from the niche to the regime level and from becoming established as a more mainstream practice before the pandemic (Burlacu, 2011a).

The purpose of this paper is to apply the same multi-level perspective (MLP) on theory of socio-technical transitions to uncover how and why telecommuting suddenly became the norm among managers and workers from various industries in the context of the global health crisis that began in early 2020 as a result of the spread of the virus Covid-19.

The practice of telecommuting has also seen changes over time, according to the same source, with the number of dependent employees who practice telecommuting increasing from 7.5 percent in 2009 to $11 \%$ in 2019 . The developments in information technology, as well as changes in the nature of professions, have both had an impact on time variations, with both providing more possibilities and flexibility to work remotely (Profiroiu et al., 2020a) (Burlacu et al., 2019).

Telecommunications, and specifically working from home, has become the standard for millions of employees around the world since the onset of a global health crisis in early 2020, according to the World Health Organization. Eurofound (2020) believes that as a result of the epidemic, 40 percent of full-time workers in the EU have begun to telecommute from home.

Prior to the pandemic, telecommuting had been a slowly rising trend in business and research as well, with the majority of its proponents claiming that it represented the future of work (Negescu Oancea, et al., 2020). Despite the promising nature of information and communications technology (ICT) and early optimist expectations, telework had mostly failed to catch the interest 
and imagination of management and employees. A multi-level perspective (MLP) on the sociotechnical transitions approach was utilized by Hynes (2016) to uncover why telecommuting has remained a 'niche' practice dominated by a narrow collection of sectors, managers, and workers. His work builds on MLP thinking by emphasizing the behavioral, cultural, and political components of socio-technical transformations and their interactions, as well as the interactions between them (Profiroiu et al., 2019). Several factors, including a failure to enroll additional niche-actors, the dominance of traditional forms of working and automobility, a lack of government policy, and a lack of legitimacy, all conspired to prevent telework from moving from the niche to the regime level and from becoming established as a more mainstream practice before the pandemic (Burlacu, 2011a).

The purpose of this paper is to apply the same multi-level perspective (MLP) on theory of socio-technical transitions to uncover how and why telecommuting suddenly became the norm among managers and workers from various industries in the context of the global health crisis that began in early 2020 as a result of the spread of the virus Covid-19.

\section{Literature review}

\section{Brief history of telecommuting}

To explain how telecommunications and related information technologies might be used to replace travel as part of an employment contract, the term "telecommuting" was first coined in the early 1970s (Caves, 2004). During the development of IT\&C, the concept of telecommuting became more prominent in popular culture during the 1990s. In 1995, the phrase "work is something you do, not something you go to" was coined to describe the concept of labor. In 1995, Woody published a paper titled Within a short period of time, variations on this motto appeared, including "Work is something we DO, not a location we GO" and "Work is what we do, not where we are."

Telecommunications-based working has been implemented by a variety of enterprises, governments, and non-profit groups prior to the epidemic (Burlacu, 2011b). It is possible that organizations will use telecommuting to save money in the future (Ioniţă et al., 2009). Employees who work from home do not require an office or cubicle (and the associated costs such as rent, lighting, climate control, and so on) (Burlacu et al., 2020). Telecommuting has been employed by certain firms to improve the quality of life of their employees, as it reduces travel time and time spent caught in traffic jams (Orzan et al., 2020). Along with this, telecommuting may play a part in improving the work-life balance of individuals by allowing them to devote more time to family duties (like caring for an elder parent or a child). Some businesses choose teleworking for environmental reasons, as it can help to minimize traffic congestion and air pollution by reducing the number of cars on the road (Costache et al., 2015). Telecommuters, in contrast to those who worked from home during the lockdown, typically maintained a traditional office and worked from an alternative work site from one to three days per week (Hill et al., 1998).

In the context of the European Employment Strategy, the European Council gave the issue of telecommuting its first serious consideration at the policy level of the EU. The Social Partners were invited to create agreements to change the way work is organized and the framework for employment interactions, according to the Council of Europe. Eurofound published a report in 2010 stating that The European Framework Agreement on Telework, which was signed on July 16, 2002, was the culmination of the discussions.

According to Parent-Thirion (et al., 2007), the average share of workers who telecommute at least a quarter of the time in the EU 27 was 7 percent, with the Czech Republic having the highest 
rate (15.2 percent), Bulgaria having the lowest rate (1.6 percent), and Malta having the lowest rate $(0$ percent $)$.

In the United States, the number of employees who have the option to work from home at least part of the time has increased dramatically over the past two decades, from 2.5 million in 2008 to 9.4 million in 2010 and more than 50 million in 2012, representing approximately $40 \%$ of the working population (Matthews and colleagues, 2012).

A study conducted by the Regus Global Economic Indicator (2013) revealed that 48 percent of business managers from all around the world worked remotely for at least half of their working week. More than 26,000 corporate managers from 90 countries took part in the study, with 55 percent of those who took part believing that efficient management of remote workers is an attainable aim. Following the release of the results, Regus CEO Mark Dixon stated: "The business people we speak with tell us that trust and freedom play a key role in remote management, and once these are in place the benefits are clear for all to see: greater productivity, improved staff retention and lower operating costs."

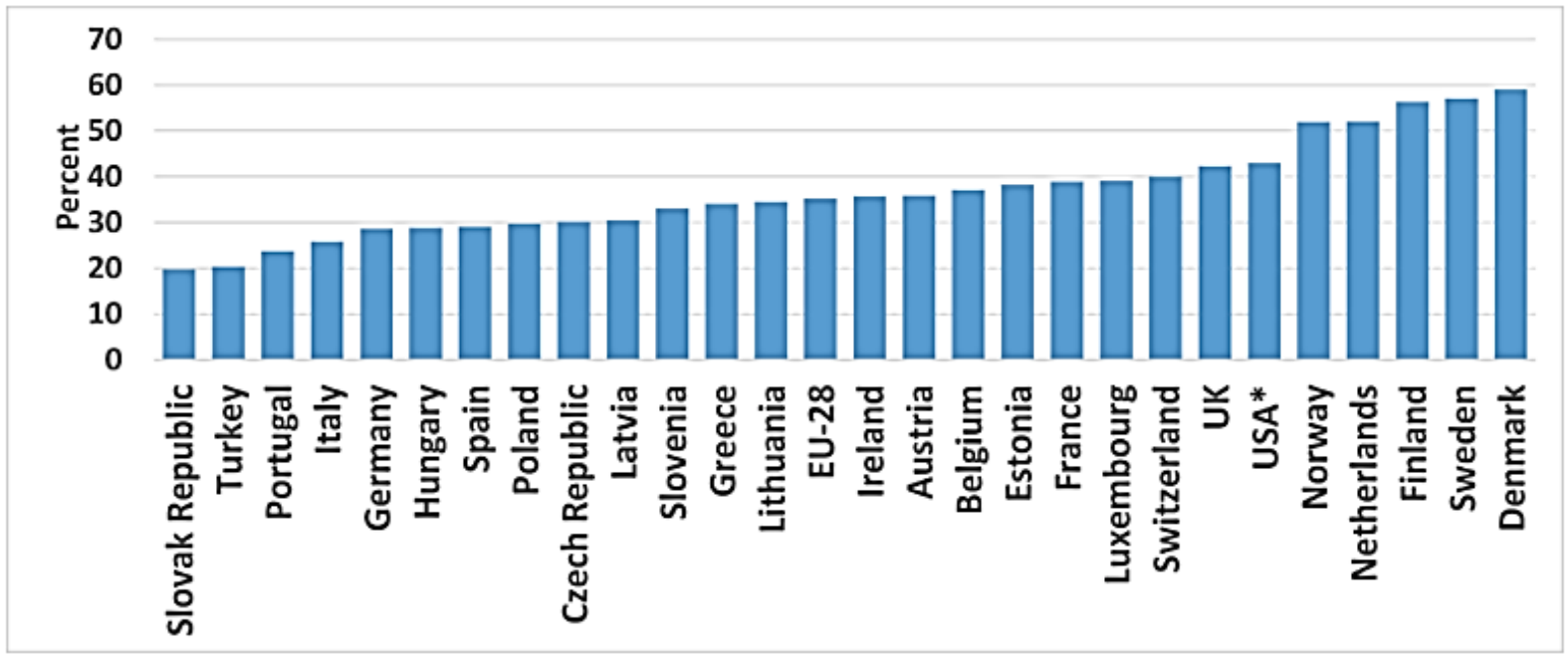

Figure 1. Use of telework varies widely across countries, Share of people using telework in 2015/2016

Source: OECD, 2020.

According to data from 2015/2016, occasional telecommuting, as depicted in Figure 1, appears to be far more prevalent than regular telecommuting in terms of frequency. However, only 12 percent of workers in Germany and 1 percent of workers in Hungary telecommuted from home at least one day per week in 2014 and 2015, respectively, while nearly 30 percent of workers in both countries tele worked on a sporadic basis in 2015, according to the International Labor Organization. In 2017, the European Foundation for Research and Development (Eurofound) published a report titled.

The level to which people telecommute varies between industries as well. It was most common in knowledge-intensive services such as professional and information and communications technology services, and least common in manufacturing and less knowledgeintensive market services such as wholesale and retail, transportation, and wholesale and retail (Bodislav et al., 2020). These discrepancies, which can be seen in Figure 2, are most likely due to the work requirements. While many high-skilled professions in knowledge-intensive industries can 
be performed remotely through the use of computers, many jobs in manufacturing are more likely to necessitate the presence of the employee in person. According to the Organization for Economic Cooperation and Development, 2020.

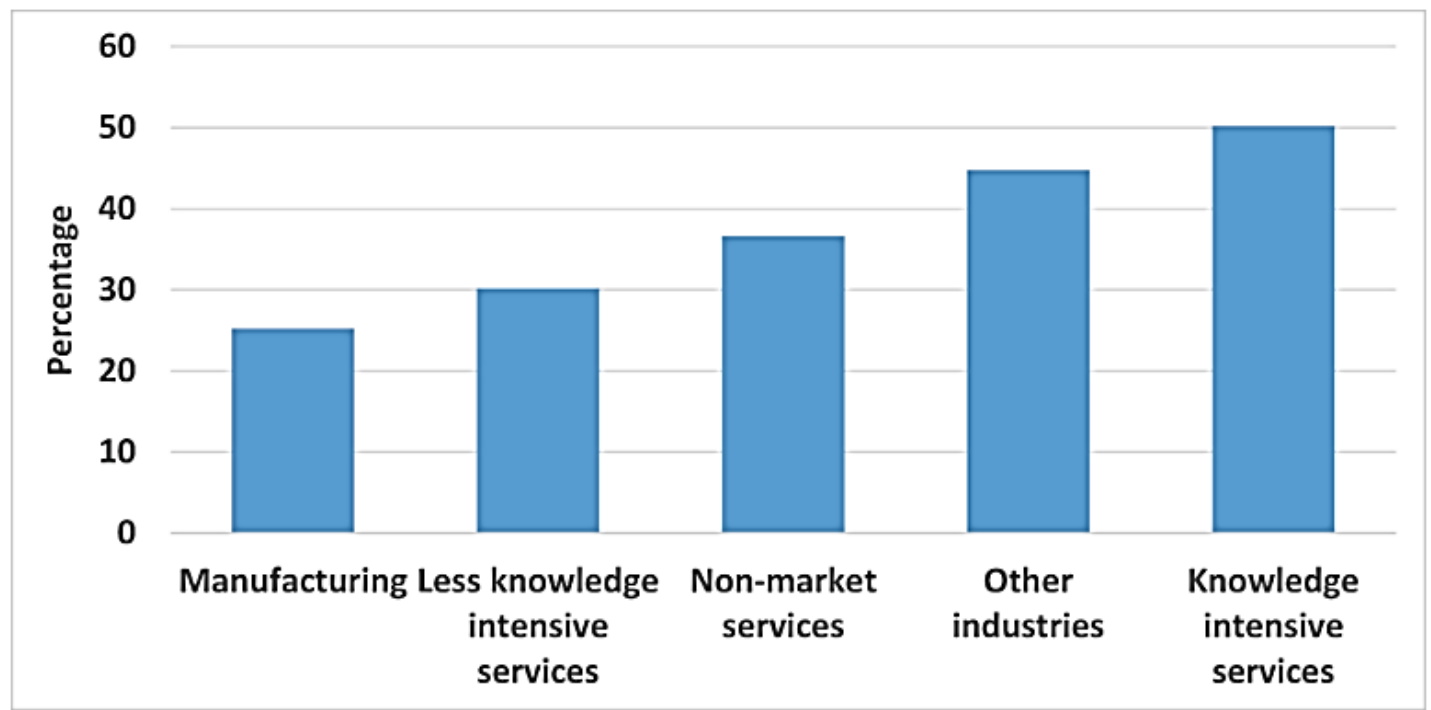

PICBE | 459

Figure 2. Use of telework varies across sectors, Cross-country average of percentage of people using telework in 2015 by sector

Source: OECD, 2020.

\section{Telecommuting as research topic}

Studies conducted on the topic of telecommuting revealed that it has economic, managerial, psycho-social, and environmental implications, among others (Profiroiu et al., 2020b).

In accordance with the literature on the economic and management aspects of telecommuting, managers may be able to deal with the difficulty of not being able to monitor the behavior of teleworkers in some situations (Felstead et al, 2003). This assumption is derived from control theory, and it refers to the process that organizations undertake to guarantee that the activities of their employees are consistent with the objectives of the business. (Jianu et al., 2019). After all, when direct monitoring of employees is not possible, control of outputs becomes more crucial, which means a greater reliance on performance indicators and targets, according to the idea (Snell, 1992).

Telecommuting studies that examine the relationship between employees' performance and their ability to work from home are also relevant to the economic and management aspects of the practice. A study by Kazekami (2020) was carried out on 9200 full-time employees who completed a questionnaire in both 2017 and 2018. The results were published in 2018. She came to the conclusion that telecommuting hours that are appropriate for the job boost labor productivity, whereas telecommuting hours that are excessively long reduce labor productivity. Telecommuting also has the added benefit of increasing life satisfaction, which leads to increased labor productivity. On the other side, telecommuting may raise the stress associated with juggling work and family duties; nonetheless, stress does not directly affect labor productivity, which is a beneficial development (Carra et al., 2018). Additionally, telecommuting happiness and workrelated satisfaction, which have no effect on labor productivity, have been found (Faggianelli et al., 2018). 
According to the literature on the environmental impact of telecommuting, working from home may have a favorable influence on traffic congestion and air pollution (Bran et al., 2018). Two large studies have been conducted in Europe, both of which were based on this broad assumption, and which sought to integrate cross-sectoral policies that have an impact on telecommuting. One of the investigations was carried out in the country of Switzerland. 5000 families participated in the survey, which was repeated 15 times until 2013. The study began in 1999 and ended in 2013. According to the findings of the study, telecommuting reduces traffic congestion by 2.7 percent on average and air pollution by 2.6 percent.

The other study, which began in 2005 in Great Britain and ended in 2012, had collected 10.516 data in single-worker homes and 6.803 observations in two-worker households by that time. Higher home telework frequencies are favorably linked with household total weekly travel for single-worker families, but this relationship appears to diminish as the size of the household increases and is not significant for two-worker households, according to Abreu e Silva (et al, 2018). Single-worker homes, by definition, have fewer persons with whom to share duties that require travel; as a result, the larger amount of weekly trip incurred by teleworkers coincides with a net rise in total weekly travel incurred by the family.

A large portion of the literature on the psycho-social dimension of telecommuting is devoted to examining the relationship between telecommuting and work-life balance.

According to Zhang (et al., 2020), from the perspective of role theory, telecommuting is a compromising strategy to meet incompatible multiple role demands since it may alleviate one type of conflict at the expense of raising another type of conflict, as described above. Different positions, such as employee, manager, husband, and parent, necessitate varying levels of time and energy commitment.

Although individuals can work from home, the compensation theory suggests that there is an inverse relationship between work and family domains, which explains why people would devote more time and energy to one of them (for example, work) in order to make up for dissatisfaction from the other domain (e.g., family) Morris and colleagues (2007)

For the sake of this article, the more modern idea of work-life balance is considered to be a distinct concept and assessment that is, in essence, conceptually as well as psychometrically distinct from conflict and enrichment (Allen, 2012). It is defined as "an overall assessment of the extent to which an individual's performance and pleasure in work and family duties are consistent with their life ideals at a particular point in time." (Greenhouse and colleagues, 2011)

\section{Methodology}

The purpose of this research is to use the multi-level perspective (MLP) to the idea of sociotechnical transitions in order to understand how and why telecommuting suddenly became the norm among managers and employees from a variety of businesses in the context of the Covid-19 healthcare crisis. 


\section{Increasing structuration}

\section{of activities in local practices}

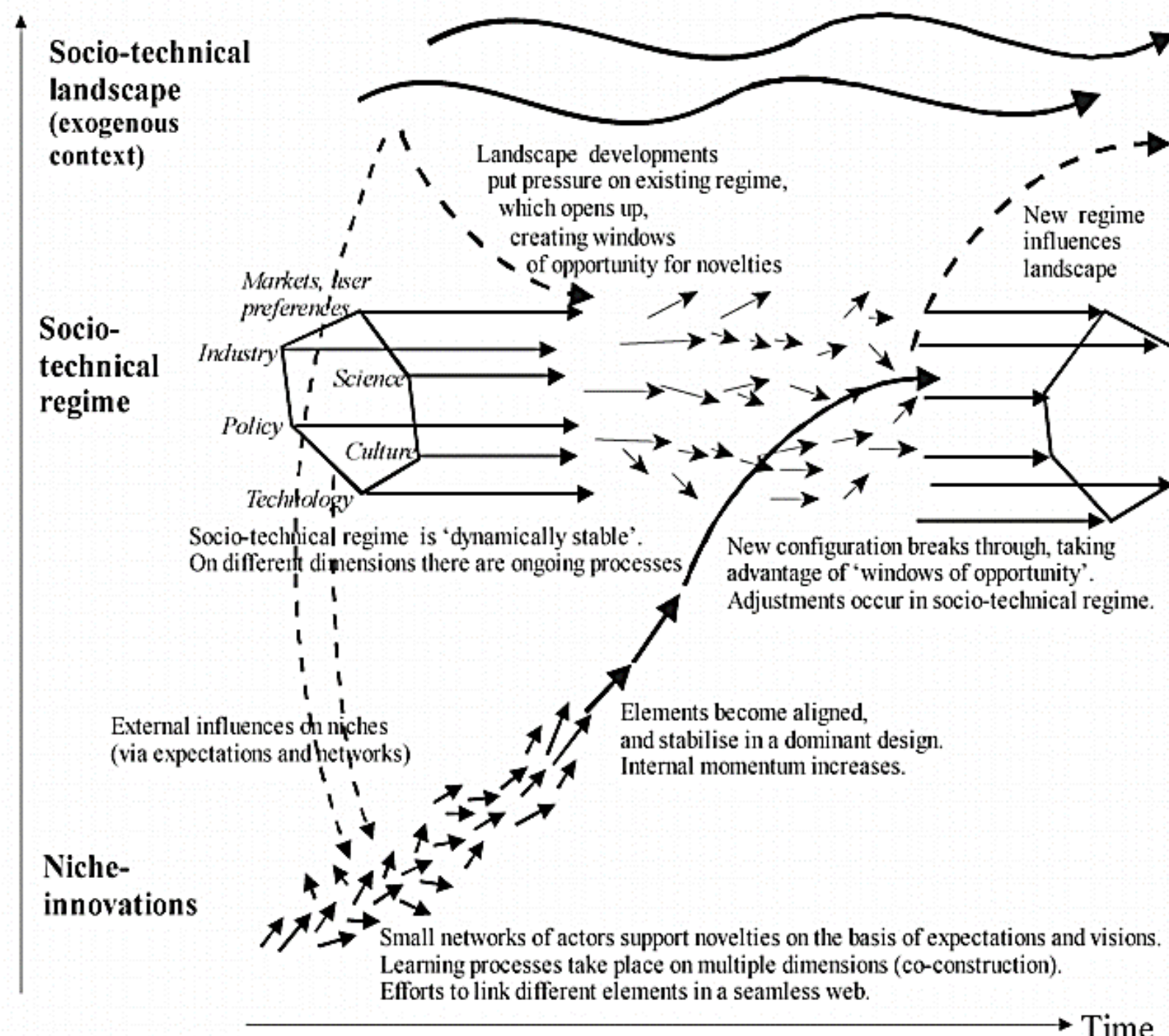

Figure 3. Multi-level perspective on transitions

Source: Geels et al., 2007.

When it comes to the concept of sociotechnical transitions, the multi-level perspective (MLP) is applied in order to understand how and why telecommuting became the norm between managers and employees from a variety of businesses during the Covid-19 healthcare crisis, which is the focus of this research.

\section{Results and discussions}

\section{Telecommuting before Covid-19 outbreak - multi-level analysis on transitions theory}

Before Covid-19 broke out, the data presented in the previous sections of this research suggested that traditional ways of working entailed traveling to the employers' premises to execute duties were the most prevalent working practices up until the emergence of Covid-19. By understanding 
the nature of telecommuting prior to the outbreak of Covid-19 and the changes and challenges that the adoption of telecommuting brought about in society, we can better understand the nature of telecommuting during the outbreak of Covid-19 as well as the changes and challenges that the adoption of telecommuting brought about in society. Figure 4 depicts the phenomenon of telecommuting as a result of a multi-level examination of socio-technical transformations, which was completed in 2016 by Hynes (2016) For example, according to Hynes (2016), in 2016 there was a constant pressure from the niche level to the regime level created by new actors (for example, companies developing software to facilitate telecommuting), individual advocates (for example, researchers proving the benefits and opportunities of telecommuting), and groups (for example, organizations advocating for telecommuting) (e.g. companies adopting telecommuting). On the other hand, the resistance to integrating telecommuting at the regime level at the niche level has diminished the interest and/or commitment of managers and employers to adopt telecommuting, as well as the ability of telecommuters to develop supporting networks and enroll new telecommuters in their programs.

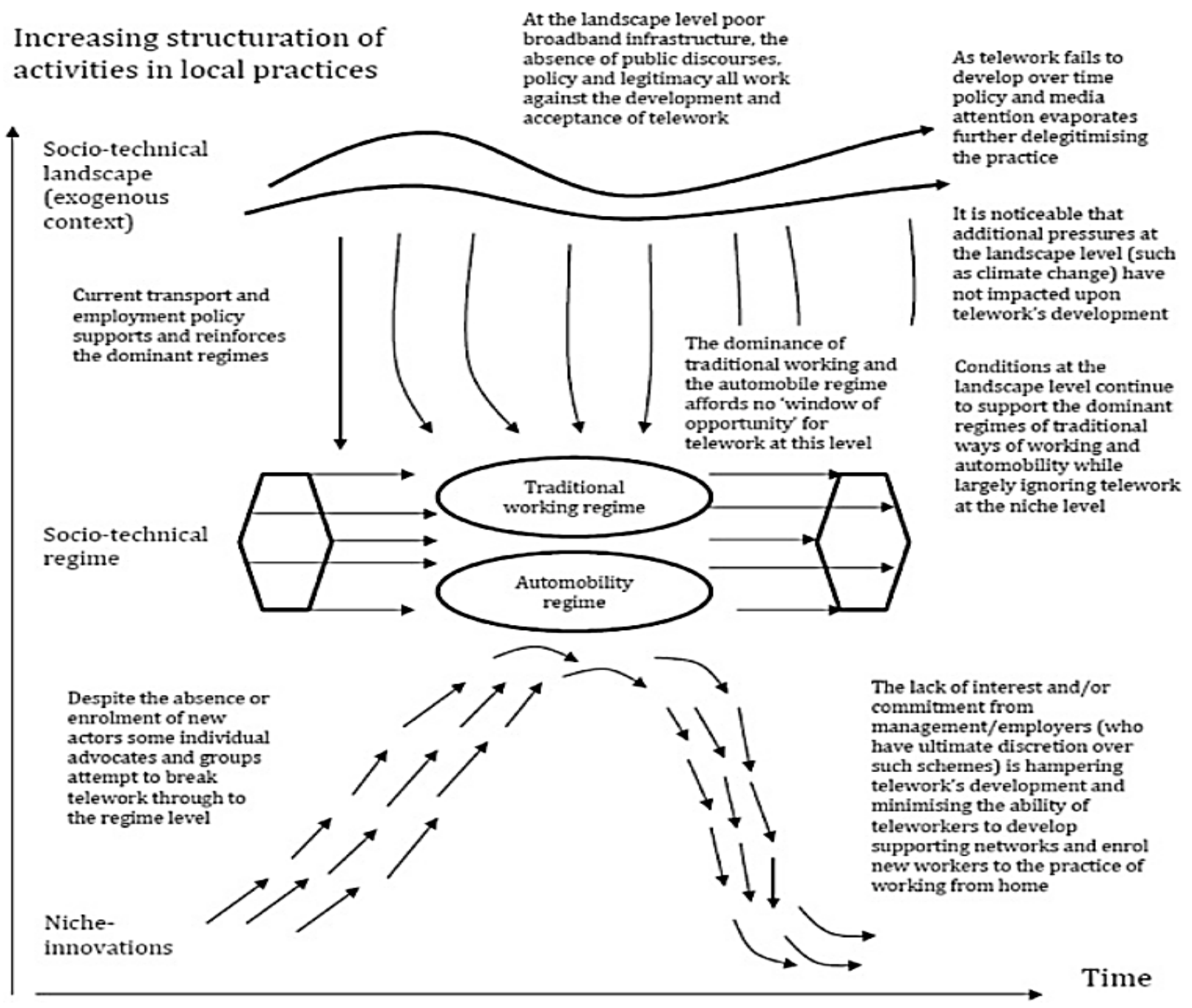

Figure 4. Telecommuting - a multi-level perspective on its socio-technical transition

Source: Hynes, 2016. 
On the level of the regime, we have conventional working patterns, along with all of the institutions, technology, practices, and dominant rules that supported them, combined with the automobility regime that made "traveling to work" a reality. According to the theory, these two regimes helped to strengthen the position of the other. On the landscape level, in the exogenous setting of conventional work and automobility, the regimes of traditional work and automobility were perpetuated by the employment and transportation policies because they did not create any windows of opportunity for niche elements to reach the regime level. Furthermore, telecommuting was absent from public debate and policy, resulting in a perceived lack of legitimacy for this practice among the public. Pre-Covid-19 outbreak, the landscape-level conditions continued to sustain the dominant regimes of traditional modes of work and automobility while generally disregarding the possibility of telecommuting. Covid-19 outbreak changed all of that.

\section{Telecommuting during Covid-19 outbreak - changes, challenges}

In light of the information reported in the preceding sections of this research, it appears that in the aftermath of the Covid-19 outbreak, telecommuting became the norm in teleworkable professions. By 2020, it is expected that almost $40 \%$ of EU workers will be telecommuting. It is possible to apply the framework of multi-level analysis to determine the factors that will be required for such a disruptive transformation to occur. At first glance, the outbreak appeared to have opened a window of opportunity at the landscape level, allowing telecommuting to burst through the nicheregime barrier. Because of the anti-pandemic actions taken by the governments, particularly the lock-down, the primary forces that were enforcing the traditional working regime and the automobility regime have abruptly shifted to the opposite side of the spectrum. Because of the requirement to work from home, managers were obligated to organize work and responsibilities in a way that made telecommuting as convenient as possible. It was during this period that niche features such as teleconference software, project management software, and the culture of telecommuting were able to penetrate the regime and establish themselves as standard operating procedures (standard operating procedures). Furthermore, these modifications were necessitated by the changes in the automobility regime. Although there were no additional limitations in place, the new procedure implemented in public space and public transportation (which included wearing a mask and maintaining physical distance) deterred both managers and employees from commuting to work. At each of the three levels, difficulties can be identified. Among the recommendations made at the landscape level was the need for a public discussion about telecommuting. This was due to the fact that the topic had not previously been thoroughly explored and debated, as well as the fact that many of the benefits and drawbacks of telecommuting were not widely known. Managers and employees have been more aware of the issue as a result of public conversations, and having public figures share their personal experiences with telecommuting has assisted many in dealing with the unpleasant aspects of this practice. In terms of regime level challenges, the desire to accept and integrate the unique components that have found a window of opportunity to become the standard presents a significant obstacle. For example, the huge number of courses, tutorials, and training programs available about telecommuting reflects this desire. Many them were tied to an industry or a sector (e.g. education). The new emergent telework regime has also had to contend with the requirements of existing regimes (e.g. family life). It is possible to think of problems as chances for innovation when dealing with niche markets. A demand has evolved at the niche level for enhancing existing technologies that allow for telecommuting, as well as leadership and management models, employee relations, and other aspects of business operations. All of the disruptive developments and problems that have arisen as a result of the new 
telecommuting regime have created both market opportunities and market failures at the same time. Further investigation on the telecommuting work regime's relationship to other work regimes, such as family life, transportation, social life, and entertainment, will be necessary in the future.

\section{Conclusion}

Until the outbreak of Covid-19, the traditional mode of working, which required employees to travel to their employers' locations in order to execute tasks, was the prevailing working practice regime. In the aftermath of the Covid-19 outbreak, telecommuting became the standard for those working in teleworkable professions.

By 2020, it is expected that almost $40 \%$ of EU workers will be telecommuting. The multilevel perspective is an analytical tool that has the ability to reflect the complexity of transitions as well as resistance to change, which is particularly useful in the context of non-linear socio-technical transitions such as the shift from traditional to telecommuting work arrangements. The outbreak of Covid-19 opened up a window of opportunity at the landscape level, allowing telecommuting to break through the niche-regime barrier for the first time. Several important factors that were previously imposing the traditional working regime and the automobility regime have unexpectedly shifted to the opposite position as a result of government anti-pandemic actions, particularly the lock-down, and the resulting chaos. Telecommuting became the norm in 2020 as a result of the requirement to stay at home, infection prevention measures (such as face masks and physical separation), and the fear of infection, as well as specialty features such as technologies that allow workers to operate remotely.

In the future, researchers may examine the evolution of telecommuting in the post-Covid19 period using the same multi-level view on socio-technical changes and make recommendations on how to best take advantage of the experience with telecommuting in 2020.

\section{References}

Abreu e Silva, J. Melo, P.C. (2018). Does home-based telework reduce household total travel? A path analysis using single and two worker British households, Journal of Transport Geography, Volume 73, 2018, Pages 148-162, ISSN 0966-6923.

Allen, T. D. (2012). The work-family role interface: A synthesis of the research from industrial and organizational psychology, Handbook of Psychology (second ed.).

Bodislav, D. A., Buzoianu, O. A. C., Burlacu, S., \& Rădulescu, C. V. (2020). Analysis of companies in Romania from the perspective of risk perception and the management needs thereof. Economic Convergence in European Union, 341.

Bran, F., Burlacu, S., \& Alpopi, C. (2018). Urban Transport of Passengers in Large Urban Agglomerations and Sustainable Development. Experience of Bucharest Municipality in Romania. European Journal of Sustainable Development, 7(3), 265-273.

Burlacu, S. (2011a). Le rôle des ONG pour la prise de conscience de l'importance des partenariats publics-prives dans l'économie sociale en Roumanie. Administratie si Management Public «(RAMP), (17), 120-129.

Burlacu, S. (2011b). THE ROLE OF NGOS IN AWARENESS OF THE PUBLIC PRIVATE PARTNERSHIP IN THE SOCIAL ECONOMY IN ROMANIA. In Proceedings of Administration and Public Management International Conference, 7(1), 118-127, Research Centre in Public Administration and Public Services, Bucharest, Romania. 
Burlacu, S., Alpopi, C., Mitrită, M., \& Popescu, M. L. (2019). Sustainable e-Governance and Human Resource Development. European Journal of Sustainable Development, 8(5), 16.

Burlacu, S., Gavrilă, A., Popescu, I. M., Gombos, S. P., \& Vasilache, P. C. (2020). Theories and Models of Functional Zoning in Urban Space. Revista de Management Comparat International, 21(1), 44-53.

Carra, C., Burlacu, S., \& Faggianelli, D. (2018). Violence within the Organizations of Health and Medico-social Sector. A Comparative Analysis of France and Romania. Economics, Management and Financial Markets, 13(3), 185-202.

Carra, C., Burlacu, S., Faggianelli, D. (2017). Violence in Health Organizations in Romania. The $13^{\text {th }}$ Administration and Public Management International Conference. Policy And Organizational Change In Public Institutions, Oct 2017, București, Romania. 〈hal$01698150\rangle$.

Caves, R. W. (2004). Encyclopedia of the City. Routledge. p. 663. ISBN 978-0415862875.

Costache, G., Marinas, C. V., Igret, R., \& Burlacu, S. (2015). Internship in the Hr DepartmentOrganizational and Individual Perspectives. In Proceedings of the International Management Conference, Vol. 9, No. 1, 359-370, Faculty of Management, Academy of Economic Studies, Bucharest, Romania.

EU (2020). Telework in the EU before and after the COVID-19: where we were.

Eurofound (2010). Telework in the European Union. Retrieved from https://www.eurofound. europa.eu/ro/publications/report/2010/telework-in-the-european-union.

Eurofound and International Labour Office (2017), Working anytime, anywhere: the effects on the world of work., Publications Office of the European Union, Luxembourg.

Eurofound, (2020). Living, working and COVID-19. Research report. Retrieved from https:// www.eurofound.europa.eu/sites/default/files/ef_publication/field_ef_document/ef20059en .pdf.

European Framework Agreement on Telework of 2002 (2002). Retrieved from https://www. eurofound.europa.eu/publications/report/2010/telework-in-the-european-union.

Eurostat (2020). Employed persons working from home as a percentage of the total employment, by sex, age and professional status (\%). Retrieved from https://ec.europa.eu/eurostat/ databrowser/view/lfsa_ehomp/default/table?lang=en.

Faggianelli, D., Burlacu, S., \& Carra, C. (2018). Victimization of Health Professionals in Bucharest Service Relations and Social Work Relationships. Administratie si Management Public, (30), 109-126.

Felstead, A. Jewson, N. Walters, S. (2003). Managerial control of employees working at home. British Journal of Industrial Relations, 41, 241-264.

Geels, F.W. (2005). Processes and patterns in transitions and system innovations: Refining the co-evolutionary multi-level perspective, Technological Forecasting and Social Change, 72(6), 681-696.

Geels, F.W. Schot, J. (2007). Typology of sociotechnical transition pathways, Research Policy, 36(3), 2007, 399-417.

Greenhaus, J. H., \& Allen, T. D. (2011). Work-family balance: A review and extension of the literature. In J. C. Quick \& L. E. Tetrick (Eds.), Handbook of occupational health psychology, 165-183.

Hill, J. E., Miller, B. C., Weiner, S. P., Colihan, J. (1998). "Influences of the virtual office on aspects of work and work/life balance", Personnel Psychology, 51(3), 667-683. doi:10.1111/j.1744-6570.1998.tb00256.x. 
Hynes, M. (2016). Developing (tele)work? A multi-level sociotechnical perspective of telework in Ireland, Research in Transportation Economics, Volume 57, 21-31, ISSN 0739-8859, https://doi.org/10.1016/j.retrec.2016.06.008.

Ionita, F., Ursacescu, M., \& Burlacu, S. (2009). Public Services as Poles of Regional Competitiveness in Sustainable Development. Revista de Management Comparat International / Review of International Comparative Management, 10(3), 552-565.

Ioniţă, F., Burlacu, S., \& Gaidargi, A. (2009). Modern Approaches of the Management of Alternative Trade Systems, Revista de Management Comparat Internațional / Review of International Comparative Management, 51, 473-480.

Jianu, I., Dobre, I., Bodislav, D. A., Radulescu, C. V., \& Burlacu, S. (2019). The Implications of Institutional Specificities on the Income Inequalities Drivers in European Union. Economic Computation and Economic Cybernetics Studies and Research, 53(2), 59-76.

Kazekami, S. (2020). Mechanisms to improve labor productivity by performing telework, Telecommunications Policy, 44(2), 101868, ISSN 0308-5961, https://doi.org/10.1016/ j.telpol.2019.101868.

Lopez-Igual, P. Rodriguez-Modrono, P. (2020). Who is Teleworking and Where from? Exploring the Main Determinants of Telework in Europe. Sustainability, 12(21), Retrieved from https://doi.org/10.3390/su12218797.

Matthews, H. Scott., Eric Williams (2012). "Telework Adoption and Energy Use in Building and Transport Sectors in the United States and Japan". Infrastruct. Syst. Special Issue: Sustainability of Transportation and other Infrastructure Systems (11), 21-30, doi:10.1061/ (ASCE)1076-0342(2005)11:1(21). ISSN 1076-0342.

Morris, M. L., and Madsen, S. R. (2007). 'Advancing Work - Life Integration in Individuals, Organizations, and Communities', Advances in Developing Human Resources, 9(4), 439-454, doi: 10.1177/1523422307305486.

Negescu, M.D., Burlacu, S., Mitriţă, M., Buzoianu, O.C.A. (2020). Managerial Analysis of Factoring at the International Level Challenges of the Contemporary Society. Proceedings; Cluj-Napoca, 13(1), 99-102, Cluj-Napoca, Babes Bolyai University.

OECD (2020). Productivity gains from teleworking in the post COVID-19 era: How can public policies make it happen?. OECD Policy Responses to Coronavirus (COVID-19). Retrieved from http://www.oecd.org/coronavirus/policy-responses/productivity-gains-from-telework ing-in-the-post-covid-19-era-a5d52e99/\#figure-d1e309.

Orzan, M. C., Burlacu, S., Florescu, M. S., Orzan, O. A., \& Macovei, O. I. (2020). The effects of online marketing on financial performance in the textile industry. Industria Textila, 71(3), 288-293.

Parent-Thirion et al. (2007). https://www.researchgate.net/publication/259884451_Fourth_ European_Working_Conditions_Survey\#fullTextFileContent).

Profiroiu, A., Burlacu, S., \& Sabie, O. (2019). Reform of the Pension System in Romania. Calitatea, 20(S2), 521-524.

Profiroiu, M.C., Bodislav, D.A., Burlacu, S., \& Rădulescu, C.V. (2020a). Challenges of Sustainable Urban Development in the Context of Population Growth. European Journal of Sustainable Development, 9(3), 51-51.

Profiroiu, M.C., Radulescu, C.V., Burlacu, S., \& Guţu, C. (2020b). Changes and trends in the development of the world economy. In Competitivitatea şi inovarea $\hat{i n}$ economia cunoaşterii, 324-330. 
Rădulescu, C.V., Bodislav, D.A., \& Burlacu, S. (2018). Demographic Explosion and it Governance in Public Institutions. Managerial Challenges of the Contemporary Society. Proceedings, 11(1), 18.

Rădulescu, C.V., Dobrea, R.C., \& Burlacu, S. (2018). The Business Management of Distress Situations. The $12^{\text {th }}$ International Management Conference "Management Perspectives in the Digital Era" Novembre $1^{\text {st }}-2^{\text {nd }}, 2018$, Bucharest, Romania, 1, 741-747.

Radulescu, C.V., Ladaru, G.-R., Burlacu, S., Constantin, F., Ioanăș, C., Petre, I.L. (2021). Impact of the COVID-19 Pandemic on the Romanian Labor Market. Sustainability 2021, 13, 271, https://doi.org/10.3390/su13010271.

Snell, A.S. (1992). Control theory in strategic human resource management: The mediating effect of administrative information, Academy of Management Journal, 35, 292-327.

Woody, L. (1995). The Underground Guide to Telecommuting. Addison-Wesley. ISBN 978-0-20148343-7.

Zhang, S., Moeckel, R., Moreno, A.T., Shuai, B., Gao, J. A (2020). work-life conflict perspective on telework, Transportation Research Part A: Policy and Practice, Volume 141, 2020, Pages 51-68, ISSN 0965-8564, https://doi.org/10.1016/j.tra.2020.09.007. 